\title{
A novel EcoRII PCR-RFLP detecting genetic variation of goat NF1-C2 gene and its association with milk yield (Brief Report)
}

\author{
Eine neuer EcoRII PCR-RFLP Nachweis genetischer Variation des Ziegengens \\ NF1-C2 und dessen Assoziation mit der Milchleistung (Brief Report)
}

Ping Wang ${ }^{1}$, Quanwu Xu², Xianyong Lan', Zhuanjian $\mathrm{Li}^{1}$, Mijie Li', Xingtang Fang ${ }^{3}$, Mingxun $\mathrm{Li}^{1}$ and Hong Chen ${ }^{1}$

${ }^{1}$ College of Animal Science and Technology, Northwest A\&F University, Shaanxi Key Laboratory of Molecular Biology for Agriculture, Yangling, China, ${ }^{2}$ Chengguan Veterinary Station, Fukang, China, ${ }^{3}$ Institute of Cellular and Molecular Biology, Xuzhou Normal University, Xuzhou, China

\section{Background}

The transcription factor nuclear factor1-C2 (NF1-C2) mediates the action of prolactin in the mammary gland. Research on the molecular genetic mechanism of model system have indicated that the NF1-C2 gene plays an important role for the activation of several mammary gland specific genes (Nilsson et al. 2006). Moreover, the effects of prolactin on milk production traits have been reported in ruminant (Seriwatanachai et al. 2008). NF1-C2 may have a similar function in goat. To our knowledge polymorphisms of NF1-C2 gene have not been described in animals. Here a SNP of the caprine NF1-C2 was detected and a EcoRII PCR-RFLP was derived, that allowed to clearly detect NF1-C2 genotypes. Further investigation was conduct to evaluate the association between polymorphisms and milk yield at different lactation stages.

\section{Procedures}

Primer sequences and $P C R$ conditions

One pair of primers was designed to amplify a 485bp fragment based on the bovine NF1-C2 gene (GenBank accession No.g. NC_007305).

P1F:5'-CCC TAC CTT AAC CCT AAC CA-3' (nt44604-nt44623);

P1R:5'-CAG GGA AAC GAA TGA ACC-3' (nt45072-nt45089).

The $25 \mu \mathrm{L}$ polymerase chain reaction (PCR) contained $50 \mathrm{ng}$ of genomic caprine DNA 0.2 $\mu \mathrm{M}$ of each primer, $1 \times$ Reaction Mix (including $\mathrm{dNTP}, \mathrm{KCl}$ and $\mathrm{MgCl}^{2}$ ) and $0.5 \mathrm{U}$ Taq DNA polymerase (Tiangen Biotech, Beijing, China). The cycling protocol was 4 min at $94^{\circ} \mathrm{C}, 34$ cycles of $94^{\circ} \mathrm{C}$ for $30 \mathrm{~s}$, annealing at $51.6^{\circ} \mathrm{C}$ for $30 \mathrm{~s}, 72^{\circ} \mathrm{C}$ for $30 \mathrm{~s}$, with a final extension at $72^{\circ} \mathrm{C}$ for $10 \mathrm{~min}$. To detect single nucleotide polymorphism (SNP) within the caprine NF1-C2 gene DNA pool (Khatib et al. 2008) was constructed from 50 different goat blood samples and the PCR products of the pooled DNA samples were sequenced in $A B I 377$. 


\section{ECoRII PCR-RFLP conditions}

A G>A transition detected at the position corresponding to nt44654 of GenBank acc. no. NC_007305 was genotyped using a ECoRII PCR-RFLP. Therefore, an alternative reverse primer was designed in which the original ' $A$ ' at nt44823 of the bovine sequence was substituted by a ' $C$ ' (bold) to avoid a EcoRIl restriction site (P2R: GTC CCG GAC TGT GAT TTG C (nt44819nt44837). PCR was carried out to amplify the 233 bp fragment of caprine NF1-C2 gene based on primers P1F/P2R. Genotyping of EcoRII PCR-RFLP within NF1-C2 allele was according to the following protocol: aliquots of $20 \mu \mathrm{L}$ PCR products of NF1-C2 gene were digested with $10 \mathrm{U}$ EcoRII (TaKaRa, Dalian, China) for $8 \mathrm{~h}$ at $37^{\circ} \mathrm{C}$. The digested products were detected by $3.0 \%$ agarose gels stained with ethidium bromide.

\section{Results}

One SNP 44654G>A (published in GenBank g. NC_007305; corresponding to position 51 in GenBank GQ169554) was detected in 776 unrelated healthy goats from three breeds in China (Xinong Saanen dairy 249, Guanzhong dairy 408, Xinjiang white cashmere 119) based on PCR and DNA-pooling sequencing approach (Khatib et al. 2008). As shown in Table 1, three different patterns were observed. The frequency of mutant allele was similar to that of wild type in dairy goats, which implied that NF1-C2 gene was less conservative at EcoRII locus.

Table 1

The genotypic and allelic frequencies of the novel SNP within goat NF1-C2 by EcoRII PCR-RFLP

\begin{tabular}{lccccc}
\hline & $\mathrm{AA}$ & $\mathrm{AG}$ & $\mathrm{GG}$ & $\mathrm{A}$ & $\mathrm{G}$ \\
\hline Xinong Saanen dairy & 0.422 & 0.056 & 0.522 & 0.450 & 0.550 \\
Guanzhong dairy & 0.402 & 0.206 & 0.392 & 0.505 & 0.495 \\
Xinjiang white cashmere & 0.176 & 0 & 0.824 & 0.176 & 0.824 \\
EcoRII PCR-RFLP & 233 & $233+186+47$ & $186+47$ & & \\
\hline
\end{tabular}

As demonstrated in a novel mechanism of prolactin signaling (Nilsson et al. 2006), prolactin modulates several mammary gland specific genes through Jak2/NF1-C2. If that is tenable, the NF1-C2 gene may have significantly association with milk production traits. To address the relationship, the association of genotype with milk yield at different lactation was analyzed (Table 2).

\section{Table 2}

Least square mean (means \pm standard error of means) of milk yield at different lactation for the alternative NF1-C2-EcoRll genotype in Xinong Saanen dairy goat

\begin{tabular}{lclc}
\hline Milk yield & AA genotype & GG genotype & $P$-value \\
\hline The first lactation & $612.967 \pm 8.760$ & $609.852 \pm 7.280$ & 0.785 \\
The second lactation & $834.006 \pm 13.071$ & $853.164 \pm 11.265$ & 0.269 \\
The third lactation & $925.225 \pm 25.116$ & $985.146 \pm 20.756$ & 0.070 \\
\hline
\end{tabular}

A total of 200 goats of Xinong Saanen dairy originated from our institute was used. Effects of year, season of birth (spring versus fall), age of dam and sire were not included in the linear model, as the preliminary statistical analyses indicated that these effects did not have 
significant influences on variability of traits in the population. The fixed effect of genotype was included as independent variable in the linear model. There were only 7 GA animals in the tested population that were excluded from the analysis. The result demonstrated that the polymorphism of the EcoRII PCR-RFLP in the goat NF1-C2 gene was not associated with milk yield; only in the third lactation genotype GG tended to be associated with higher milk yield than genotype AA. Although NF1-C2 has an important role in milk gene activation, the NF1-C2 protein levels are reduced at lactation, when milk genes are most highly expressed (Johansson et al. 2005). Our results are in accordance with the hypothesis that the NF1-C2 gene participates in the establishment of mammary gland but not the maintenance of milk gene expression which influences milk yield.

\section{Acknowledgements}

This work was supported by the National »863 «Program of the P.R. China (No. 2008AA10Z138), Research Fund for the doctor Program of Higher Education of China (No. 20080712012), Natural Science Foundation of Jiangsu Province (No. BK2008120), the Young Topnotch Researcher Support Project of Northwest A\&F University (No. QNGG-2009-007).

\section{References}

Johansson EM, Kannius-Janson M, Gritli-Linde A, Bjursell G, Nilsson J (2005) Nuclear factor 1-C2 is regulated by prolactin and shows a distinct expression pattern in the mouse mammary epithelial cells during development, Mol Endocrinol 19, 992-1003

Khatib H, Monson RL, Schutzkus V, Kohl DM, Rosa GJM, Rutledge JJ (2008) Mutations in the STAT5A gene are associated with embryonic survival and milk composition in cattle, J Dairy Sci 91, 784-793

Nilsson J, Bjursell G, Kannius-Janson M (2006) Nuclear jak2 and transcription factor NF1-C2: A novel mechanism of prolactin signaling in mammary epithelial cells, Mol Cell Biol 26, 5663-5674

Seriwatanachai D, Charoenphandhu N, Suthiphongchai T, Krishnamra N (2008) Prolactin decreases the expression ratio of receptor activator of nuclear factor kappa $b$ ligand/osteoprotegerin in human fetal osteoblast cells, Cell Biology International 32, 1126-1135

Received 28 May 2009, accepted 3 November 2010.

Corresponding author:

Hong Chen

email: chenhong1212@263.net

College of Animal Science and Technology, Northwest A\&F University, Shaanxi Key Laboratory of Molecular Biology for Agriculture, Yangling, Shaanxi 712100, China 